\title{
HUBUNGAN ANTARA TINGKAT STRES DENGAN BEBAN KERJA GURU DI SEKOLAH LUAR BIASA
}

\author{
Fandi Muhbar ${ }^{1}$, Dwi Heppy Rochmawati ${ }^{2}$ \\ ${ }^{1}$ Mahasiswa Fakultas Ilmu Keperawatan, Universitas Islam Sultan Agung Semarang \\ ${ }^{2}$ Dosen Keperawatn Jiwa Fakultas Ilmu Keperawatan, Universitas Islam Sultan Agung Semarang \\ dwiheppy@unissula.ac.id
}

\begin{abstract}
ABSTRAK
Stres adalah suatu kondisi ketegangan yang bisa mempengaruhi emosi seseorang, proses berpikir, khawatir, gelisah dan takut. Stres dapat terjadi pada siapa pun dan di mana pun, termaksud pada guru yang berada di SLB. Setiap guru mengalami stres dari berbagai macam sumber seperti beban kerja yang terlalu berat, sampai dengan kondisi kerja yang tidak memuaskan. Penelitian ini bersifat analitik observasional dengan desain cross sectional. Pengumpulan data dilakukan dengan kuesioner dan wawancara. Jumlah responden sebanyak 30 orang dengan teknik total sampling. Data yang diperoleh diolah secara statistic dengan menggunakan uji spearman. Penelitian dengan jumlah responden 30 guru di dapatkan hasil hubungan antara tingakat stres dengan beban kerja guru SLB, diperoleh significancy 0,044 ( $p$ value $<0,05$ ). Diharapkan ada upaya yang dapat diberikan untuk mengurangi tingkat stres dan beban kerja guru tersebut.
\end{abstract}

Kata kunci: Tingkat stres, Beban kerja, SLB

\section{THE RELATIONSHIP BETWEEN LEVEL STRESS WITH WORKLOAD OF TEACHERS IN EXTRAORDINARY SCHOOL}

\begin{abstract}
Stress is a condition of tension that can make a person's emotions, thought process,worry, anxiety and fear. Stress can happen to anyone and anywhere, including on teachers in extraordinary schools.Every teacher under stress from a variety of sources such as the workload is too heavy, to the working conditions unsatisfactory. This is an analytical observational study with cross sectional design. The data were collected using questionnaire and interview. There were 30 respondents obtained using total sampling technique. The obtained data were analyzed statistically using Spearman correlational test. The research with respondents 30 teachers obtained the relationship between stress levels with the workload of teachers in extraordinary school obtained significant 0,44 ( $p$ value<0,05. Expected efforts can be given to reduce the stress level and the workload of the teacher.
\end{abstract}

Keywords: Stress levels, workload, extraordinary schools

\section{PENDAHULUAN}

Stres adalah sesuatu yang dapat menimbulkan ketegangan yang dapat mempengaruhi emosi seseorang, proses Berpikir pada kondisi setiap orang. Stres merupakan bagian dari suatu kondisi manusiawi karena semua manusia yang hidup di muka bumi ini pasti merasakan kecewa takut, resah, khawatir, gelisah, dan sedih karena masalah yang sedang dihadapi di dalam hidup mereka akan dating silih berganti tanpa adanya rekayasa dari dirimereka sendiri. Setiap manusia pasti memiliki keinginan, harapan, dan cita-cita, dalam hidup mereka, untuk menggapais emua keinginan, harapan dan cita-cita, tersebut maka pada setiap manusia akan mendapatkan tantangan, hambatan, maupun gangguan, sangat jarang sekali jika kita bias menggapai semua keinginan kita dengan begitu mudah, tantangan, gangguan dan hambatan itu nantinya yang akan menjadi sumber masalah penyebab stres. ( Rineka, 2006).

Stres juga kadang-kadang di ibaratkan seperti dua sisi mata uang yang berbeda namun keduanya tidak dapat dipisahkan. Satu sisi kita memanfaatkan stres agar potensi diri lebih terasah namun disisi lain karena stress manusia menjadi merugi dan depresi. Hal yang terpenting adalah bagaimana seseorang mampu menjadikan stress sebagaimotivasi dalam kehidupan sehingga, setiap masalah yang dating silih berganti bias dilewati dan diselesaikan dengan baik.(Intan, 2009). 
Menurut badan Kesehatan Dunia, mengatakan 3 permil dari sekitar 32 juta warga didaerah Jawa Tengah mengalami ganguan jiwa sedangkan 19 permil mengalami stres. Apabila jumlahnya dipresentasikan akan mencapai sekitar $2,2 \%$ dari total warga Jawa Tengah. Stres dapat ditimbulkan, yaitu karakteristik seseorang yang merupakan bagian dari predisposisi keturunan dan pikologi sorang tersebut. Selain itu pengaru lingkungan misalnya pengalaman masa lalu dan lingkungan tempat tinggal.Sehingga munculnya stress akibat dari faktor dari diri individu dan dari dalam diri individu itu sendiri (Acevedo dan Ekkekakis, 2006).

Guru mempunyai hak untuk mendidik generasi bangsa, sehinga guru tidak terlepas dari kemungkinan mengalami stres dalam pekerjaanya. Salah satu kondisi yang dapat berpengaruh terhadap kinerja dan produktivitas individu adalah stres.Stres merupakan keadaan psikologis yang tidak menyenangkan yang muncul karena karyawan tertekan dalam bekerja, Stres ini akan muncul dengan adanya gejala fisik, psikis dan perilaku (Wijono 2010 dalam Beriko Putr anta Taringan, 2015).

Menurut penelitian Arismunandar (2008) disimpulkan bahwa 30,27\% dari 80.000 guru menderita stres dalam bekerja. Ini berarti jumlah guru yang mengalami stres dalam bekerja sebanyak 24,000 orang. Menurut studi yang di lakukan, bahwa stres dalam bekerja akan mempengaruhi kinerja pada guru, semakin tinggi tingkat stres yang dialami oleh guru, maka produktivitas dan kinerja pada guru akan mengalami penurunan.. Selain itu menurut, Indriyani (2009) ketidak mampuan guru menggatasi masalah dengan baik, seperti masalah dalam keluarga akan menimbulkan konflik dalam pekerjaan yang akan berpengaruh pada pekerjaan sehingga timbul stres dalam bekerja.

\section{METODE}

Penelitian ini merupakan penelitian kuantitatif operasional dengan pendekatan cross sectional studi. disain penelitian ini hanya di lakukan dalam satu kali. Populasi dalam penelitian adalah guru di SLB di kota Semarang sebanyak 30 responden. Sampel dalam penelitian ini adalah bagian dari total populasi yang dapat mewakili kejadian beban kerja guru di SLB. Teknik pengambilan sampel pada penelitian ini adalah total sampling. Instrumen yang digunakan dalam penelitian ini berupa kuesioner.Kuesioner yang digunakan terdiri dari dua bagian yaitu bagian A berisi tentang kuesioner beban kerja dan bagian B tentang tingkat Stres.

\section{HASIL}

Penelitian ini terdapat berbagai karakteristik responden yaitu umur, jenis kelamin, pendidikan, lama bekerja, tingkat stres, beban kerja. Jumlah responden sebanyak 30 guru tentunya akan memiliki tingkat stres dan beban kerja yang berbeda-beda, sehingga peneliti mendeskripsikan hasil penilitian dari setiap guru tersebut dan menyajikan hasil penelitian dalam bentuk tabel distribusi frekuensi sebagai berikut:

Tabel 1.

Karakteristik Responden ( $n=30$ orang )

\begin{tabular}{|c|c|c|}
\hline Variabel & $\mathrm{f}$ & $\%$ \\
\hline \multicolumn{3}{|l|}{ Usia } \\
\hline$<30$ & 7 & 23,3 \\
\hline $31-40$ & 11 & 36,7 \\
\hline $41-50$ & 12 & 40 \\
\hline Jenis Kelamin & & \\
\hline Laki-laki & 14 & 46,7 \\
\hline Perempuan & 16 & 53,3 \\
\hline Pendidikan & & \\
\hline Sarjana & 21 & 70 \\
\hline Magister & 9 & 30 \\
\hline Lama Kerja & & \\
\hline$<5$ tahun & 17 & 56,7 \\
\hline 6-10 tahun & 9 & 30,0 \\
\hline$>10$ tahun & 4 & 13,3 \\
\hline
\end{tabular}


Tabel 2.

Tingkat Stres responden $(\mathrm{n}=30$ guru $)$

\begin{tabular}{lcc}
\hline Tingkat Stres & $\mathrm{f}$ & $\%$ \\
\hline Tidak stres & 4 & 13,3 \\
Stres sedang & 8 & 26,7 \\
Stres berat & 18 & 60,0 \\
\hline
\end{tabular}

Tabel 3.

Beban kerja responden $(\mathrm{n}=30$ guru $)$

\begin{tabular}{lcc}
\hline Beban kerja & $\mathrm{f}$ & $\%$ \\
\hline Ringan & 8 & 26,7 \\
Sedang & 9 & 30,0 \\
Berat & 13 & 43,3 \\
\hline
\end{tabular}

Tabel 4.

Hubungan Tingkat Stres dengan beban kerja responden

\begin{tabular}{|c|c|c|c|c|c|c|c|c|}
\hline \multirow{3}{*}{$\begin{array}{l}\text { Tingkat } \\
\text { Stres }\end{array}$} & \multicolumn{6}{|c|}{ Beban kerja } & \multirow{3}{*}{$P$ value } & \multirow{3}{*}{$\begin{array}{l}\text { Correlation } \\
\text { Coefficient }\end{array}$} \\
\hline & \multicolumn{2}{|c|}{ Berat } & \multicolumn{2}{|c|}{ Sedang } & \multicolumn{2}{|c|}{ Ringan } & & \\
\hline & $\mathrm{f}$ & $\%$ & $\mathrm{f}$ & $\%$ & $\mathrm{f}$ & $\%$ & & \\
\hline Tidak stres & 1 & 25,0 & 1 & 25,0 & 2 & 50 & & \\
\hline Stres sedang & 1 & 12,5 & 5 & 62,5 & 2 & 25 & 0,044 & $-.370^{*}$ \\
\hline Stres berat & 11 & 61,1 & 3 & 16,7 & 4 & 22,2 & & \\
\hline
\end{tabular}

Hasil uji Spearman pada tabel 4 menunjukkan seharusnya di sesuaikan dan diseimbangkan bahwa dari hasil diperoleh significancy 0,044 ( $p$ value<0,05) yang menunjukkan bahwa korelasi antara tingkat stres dengan beban kerja pada guru adalah bermakna. Nilai korelasi spearman ranksebesar $-0,370$ yang menunjukkan bahwa kekuatan korelasi rendah/lemah dengan arah korelasi negatif, artinya tingkat stres yang berat maka beban kerja semakin berat, dan ada hubungan yang bermakna antara tingkat stres dengan beban kerja pada guru di sekolah luar biasa negeri Semarang.

\section{PEMBAHASAN}

\section{Tingkat Stres}

Menurut Fitria (2008), dalam Beriko Putranta Taringan (2015) mengemukakan "Stress dapat terjadi pada siapa pun dan di mana pun, termasuk pada guru. Pekerjaan mengajar dapat dikategorikan sebagai pekerjaan yang taraf stresnya tinggi. Stres pada dunia pekerjaan dapat diakibatkan karena beban kerja yang berat dan bisa diakibatkan karena beban kerja yang ringan atau santai, sehingga membuat seseorang menjadi stres kerja.

\section{Beban Kerja}

Beban kerja menurut Munandar (2001) pada setiap beban kerja yang di berikan seseorang dengan kemampuan fisiknya, pada kemampuan kognitif maupun keterbatasan yang dimiliki manusia yang diberikan beban kerja tersebut. Dikarenakan semakin berat beban kerja seseorang yang di kerjakan, maka akan menghasilkan stres kerja yang tinggi.

Beban kerja akan menghasilkan stres pada lingkungan kerja, gejala yang terlihat adalah kurangnya kepuasan kerja, meningkatnya detak jantung, suka marah-marah dan motivasi kerja yang rendah. Selain beban kerja, pekerjaan yang sedikit cenderung akan membuat seseorang menjadi bosan dengan pekerjaannya.

\section{Hubungan antara Tingkat Stres dan beban kerja}

Menggunakan uji Spearman menunjukkan hasil $p$ value $0,044 \quad(<0,05)$ berarti ada hubungan antara tingkat stres dengan beban kerja pada guru. Nilai korelasi spearman rank sebesar $-0,370$ yang menunjukkan bahwa kekuatan korelasi rendah/lemah dengan arah korelasi negatif, artinya semakin berat beban kerja guru maka tingkat stress akan semakin berat. 
Stres dalam dunia pekerjaan sering terjadi pada seseorang yang puas dengan pekerjaanya, ada banyak hal yang membuat kita stres pada lingkungan kerja. Di antaranya kurang cocoknya kita terhadap atasan atau bawahan, dan lingkungan kerja yang kurang memuaskan sehingga membuat kita sulit untuk berkembang dalam lingkungan kerja. Memberitahukan minat anda kepada atasan atau bawahan dapat menolongnya. Namun, bila tidak ada perubahan, meninggalkan komunitas dan lingkungan kerja bagi seseorang adalah lebih baik.

Hubungan seseorang di luar dari lingkungan keluarga mampu menghasilkan banyaknya sumber stres contohnya adalah hampir setiap orang akan mengalami stres yang berhubungan dengan lingkungan kerjanya. Hal ini di karenakan tuntutan kerja yang ada. Ada dua yang membuat seseorang stres di lingkungan kerja pertama tuntutan pekerjaan yang tinggi, sebagai akibat untuk mendapatkan sesuatu misalnya penghasilan yang tinggi atau jabatan yang lebih tinggi, dua apa bila jabatan yang ditaganinya tidak sesuai dengan kemampuannya.

\section{SIMPULAN DAN SARAN \\ Simpulan}

Simpulan yang didapatkan dari hasil penelitian ini adalah sebagai berikut:

1. Usia terbanyak yaitu 41-50 tahun sejumlah 12 guru (40\%) jenis kelamin perempuan sebanyak 23 orang $(63,9 \%)$ pendidikan sarjana sejumlah 21 guru (70\%) lama bekerja $<5$ th sejumlah 17 guru $(56,7 \%)$

2. Tingkat stres responden terbanyak stres berat sejumlah 18 guru $(60,0 \%)$

3. Beban kerja responden terbanyak adalah beban kerja berat sejumlah 13 guru $(43,3 \%)$, sedangkan beban kerja ringan sebanyak 8 guru $(26,7 \%)$.

4. Ada hubungan antara tingkat stres dengan beban kerja guru di sekolah luar biasa dengan significancy 0,044 ( $p$ value $<0,05$ ).

\section{Saran}

Penelitian selanjutnya diharapkan ada intervensi yang dapat diberikan untuk mengurangi tingkat stres dan beban kerja guru tersebut.

\section{DAFTAR PUSTAKA}

Arismunandar, (2008). Perilaku organisasi dalam pendidikan, makassar: Badan penerbit universitas negeri makassar indonesia.

Arismunandar. (2008). 24.000 Guru di Sulawesi Selatan Menderita Stress Berat. dalam www.forumsdm.org. Dikutip tanggal 26 Oktober 2016.

Chandra, B. (2009). Metodologi Penelitian Kesehatan. Jakarta : EGC

Delphie, B. (2009). Bimbingan Perilaku Adaptif Anak dengan Hendaya Perkembangan Fungsional. Klaten : Intansejati.

Efendi, F (2009). Keperawatan kesehatan komunitas: teori dan praktek dalam keperawatan. Jilid . jakarta: salemba medika.

Eres, F \& Atanasoska, T. (2011). Occupational Stress of Teacher : A Comparative Study Between Turkey and Macedonia. International Journal of Humanities and Social Science.

Fathoni, A.R. (2006). Organisasi dan Manajemen Sumber Daya Manusia. Jakarta : Rineka Cipta.

Hariyati, M. (2011). Pengaru Beban kerja Terhadap Kelelahan Kerja pada pekerja Linting Manual Di PT.Djitoe Indonesia Tobacco Surakarta. Skripsi. Universitas Sebelas Maret Surakarta.

Hawari, (2008). Manajemen stress cemas dan depresi. Jakarta: FK Universitas Indonesia.

Hawari, D. (2007). Manajemen Stres, Cemas dan depresi.

Hidayat, A. A. (2007). Riset Keperawatan dan Teknik Penulisan Ilmiah Edisi ke 2 Jakarta : Salemba Medika.

Indriyani,A.(2009). Pengaruh konflik peran ganda dan stress kerja terhadap kinerja 
perawat rumah sakit : Universitas Muhammadiyah malang

Lazarus \& Folkman (2012). Stress appraisal and coping. New York : spinger publishing company, inc.

Nasir abdul \& Muhith abdul (2011) Dasar dasar keperawatan jiwa. Jakarta, Salemba Medika, 2011

Nasir abdul (2011). Dasar-dasar keperawatan jiwa pengantar dan teori salemba medika: jakarta

Notoatmodjo, S.(2010). Metodologi Penelitian Kesehatan. Jakarta : Rineka Cipta.

Nursalam. (2013). Metodologi Penelitian Ilmu Keperawatan : Pendekatan Praktis Edisi 3. Jakarta : Salemba Medika.

Sastroasmoro, S.(2014). Dasar - Dasar Metodologi Penelitian Klinis Edisi ke-5. Jakarta : Sagung Seto.
Stuart, G. W.(2013). Prinsip dan Praktik Keperawatan Kesehatan Jiwa.Stuart.

Taringan. (2015). Gambaran Sumber Stres (stresor) Pada Guru SLB.Markus Medan

Videbeck, (2008). Buku ajar keperawatan jiwa. Jakarta: EGC.

Wijono, sutarto.(2010). Pisikologi industri dan organisasi. Jakarta: kencana.

Winarsuna, T. (2008) psikologi keselamatan kerja, Malang: UMM Press

Winarsunu (2008) pisikologi keselamatan kerja, malang: penerbitan. Universitas Muhammadiyah Malang. 